\title{
Pazar Odaklılık, Marka Yönetim Yetenekleri ve Örgütsel Performans İlişkisi: Otomotiv Sektöründe Bir Alan Araştırmasi ${ }^{1}$
}

\author{
Sena Erden Ayhün ${ }^{a^{*}}$, Mehmet Fatih Külcü ${ }^{b}$ \\ aÇanakkale Onsekiz Mart Üniversitesi, Çanakkale Sosyal Bilimler MYO, Çanakkale. \\ ${ }^{b}$ Uludă̆ Üniversitesi, İşletme Anabilim Dalı Doktora Öğrencisi
}

\begin{abstract}
$\ddot{O} z$
Günümüz piyasalarnda rekabetin küresel boyutlara ulaşması, örgütsel performans düzeyini artırmak isteyen işletmelerin marka yönetim yeteneklerine ve pazar odakl davranışlara önem vermesi gerekliliğini beraberinde getirmiştir. Çalışmada otomotiv sektöründe faaliyette bulunan işletmelerinin pazar odaklllk, marka yönetim yetenekleri ve örgütsel performans düzeyleri arasındaki ilişkinin yönü ve düzeyi belirlenmeye çalışılmıştır. Çalışmada uygulanan anket iki ana bölümden oluşmuş, ilk bölümde sektörde bulunan işletmelerin demografik özelliklerine ve tanımlayıc istatistiklerine yer verilmiştir. İkinci bölümde ise; marka yönetim yetenekleri, pazar odaklllık ve örgütsel performans ölçekleri yer almıştır. Verilerin analizinde yapısal eşitlik modeli, doğrulayıcı faktör analizi ve frekans analizlerinden yararlanılmışıı. Çalışmada yer alan ölçeklerin güvenilirlik analizleri de araştırılmış, güvenilirlik analizleri doğrulayıcı faktör analizi ile birlikte değerlendirilmiştir. Yapılan analizler sonucunda; pazar odaklllk, marka yönetim yetenekleri ve örgütsel performans düzeyinin birbirlerini pozitif yönlü ve anlamlı olarak etkilediği bulgusuna ulaşılmıştır.
\end{abstract}

Anahtar kelimeler: Pazar Odaklllk, Örgütsel Performans, Marka Yönetim Yeteneği, Yönetim, Stratejik Yönetim

\section{Relationship Among Market Focus, Brand Management Capabilities and Organizational Performance: A Field Survey in the Automotive Sector}

\begin{abstract}
Brand management capabilities and market orientation in today's markets, where competition has reached global dimensions have become an important element to improve the level of organizational performance. In this study, it was attempted to determine whether there is a relationship between market orientation, organizational performance levels and brand management capabilities in the automotive sector. The questionnaire consists of two parts and in the first part, demographic characteristics and descriptive statistics of enterprises in the industry are included. The second part involves market orientation, brand management capabilities and organizational performance scales. In data analysis, structural equation modelling, confirmatory factor analysis, frequency analysis are used. The reliability analyses of the scales are also investigated and the reliability analyses are evaluated together with confirmatory factor analysis. It has been determined that there is a positive and significant effect among market orientation, brand management capabilities and organizational performance level in the automotive sector.
\end{abstract}

Keywords: Market Orientation, Organizational Performance, Brand Management Capabilities, Management, Strategic Management

\footnotetext{
${ }^{1}$ Bu çalışma Mehmet Fatih Külcü'nün Dr. Öğr. Üyesi Sena Erden Ayhün danışmanlığında hazırlamış olduğu (2017); "Marka Yönetim Yetenekleri ve Örgütsel Performans İlişkisi: Otomotiv Sektöründe Bir Alan Araştırması başlıklı yüksek lisans tezinden üretilmiştir.
}

*Yazışma adresi. Email: senaerden@comu.edu.tr 


\section{GİRIŞ}

Sanayi devrimi ile birlikte makineleşmenin ortaya çıkması, işletmelerin daha az emek gücü ile daha fazla ürün/hizmet üretebilmelerine olanak tanımıştır. Emek gücünün azalmasıyla birlikte maliyetlerde yaşanan düşüşler yeni işletmelerin kurulmasına ve böylece günümüz rekabet koşullarının ortaya çıkmasına ortam hazırlamış, zamanla bilgi ve iletişim teknolojilerindeki gelişmelerin de etkisiyle kıtalar arası ticaretin dâhi mümkün olduğu günümüz piyasa yapısı işletmeleri etkisi altına almıştır. Zaman içerisinde gelişen teknolojiyle birlikte emek gücüne duyulan ihtiyacın azalması, dolayısıyla artan makineleşmeyle beraber işletmelerin maliyetlerini düşürerek kârlılıklarını arttırma ve daha fazla satış yapabilme düşünceleri marka yönetim yetenekleri ve pazar odaklılık kavramlarının önem kazanmasını beraberinde getirmiştir.

İşletmelerin günümüz rekabet koşullarında mücadele etmelerinin, sürekli değişen pazar koşullarına yönelik yeni politika ve stratejilerle çözümler getirmelerinin ve en önemlisi de pazar paylarını artırabilme çabalarının altında yatan temel unsuru örgütsel performanslarını artırabilme düşüncesi oluşturmaktadır. Ürün/hizmet piyasasında eş biçimliliğin yaşandığı günümüzün yoğun rekabet ortamında işletmelerin örgütsel performans düzeylerinin artmasında marka yönetim yetenekleri ve pazar odaklı uygulamaların etkili ve verimli olarak yönetilebilmesi önemli bir konu haline gelmiştir.

Çalışmada pazar odaklılık, marka yönetim yetenekleri ve örgütsel performans kavramları açıklanmıştır. Buna ilaveten çalışmanın araştırma kısmında pazar odaklılık, marka yönetim yeteneği ve örgütsel performans kavramları arasındaki ilişkilerin yönü ve düzeyi belirlenmeye çalışılmıştır.

\section{LITERATÜR TARAMASI}

Çalışmanın bu kısmında; pazar odaklılık kavramı, pazar odaklılı̆̆ın alt boyutları olarak ifade edilen rakip odaklılık, müşteri odaklılık ve işlevler arası koordinasyon kavramları, müşteri ilişkileri yönetim yetenekleri ve örgütsel performans kavramları açıklanmış ve literatürdeki konuyla ilgili daha önce yapılan çalışmalardan bahsedilmiştir.

\subsection{Pazar Odaklılık Kavramı}

Günümüzde küresel bir boyut kazanan piyasalar, işletmeleri yoğun rekabet koşulları ile mücadele etmek zorunda bırakmıştır. Bu bağlamda işletmelerin yoğun rekabet koşullarına rağmen ürünlerini/hizmetlerini pazarlayabilmelerine yönelik strateji arayışları neticesinde ileri sürülen ve birçok araştırmaya konu olan pazar odaklılık yaklaşımı ortaya çıkmıştır.

Literatürde yapılan çalışmalar incelendiğinde, pazar odaklılığın iki farklı yönden ele alındığı dikkat çekmektedir (Kohli ve Jaworski, 1990: 3; Narver ve Slater, 1990: 21); 
- Pazar odaklılık; tüm işletme çalışanları tarafından, hedef tüketici kitlelerinin bugünkü ve gelecekteki ihtiyaçları ile söz konusu ihtiyaçlarını etkileyen unsurların neler olduğuna yönelik bilgilerin toplanması, toplanan verilerin işletme birimleri içerisinde yayılması ve tüm çalışanların söz konusu verilere odaklı bir şekilde faaliyetlerini sürdürmesi şeklinde açıklanmaktadır.

- Diğer bir yönüyle pazar odaklılık; işletmelerin hedef tüketici kitlelerine, daha yüksek değerler sağlamalarında yardımcı olacak tutum ve davranışların en doğru ve güvenilir bir şekilde belirlenmesi ve uygulanması odaklı kurum kültürü olarak ifade edilmektedir.

İşletmelerin faaliyette bulundukları piyasalarda ürünlerini/hizmetlerini tanıtan, marka kimliği, marka çağrışımları, marka bilinirliği, marka farkındalığı, marka değeri vb. unsurların etkili bir şekilde yönetilmesini ifade eden marka yönetim yeteneklerinin etkinliğinde pazar odaklılık yaklaşımı önemli rol oynamaktadır (Rose ve Shoham, 2002: 218). Pazar odaklı uygulamalar, işletmelerin tüketici ihtiyaç ve beklentilerini en kısa sürede karşılayacak stratejileri belirlemeleri, söz konusu stratejilerin tüm işletme çalışanları tarafından benimsenerek uygulanması şeklinde açıklanmaktadır. Bu noktada pazar odaklı uygulamaların, işletmelerin hedef tüketici kitlelerinin ihtiyaçlarına ve beklentilerine rakiplerinden daha hızlı bir şekilde cevap verebilecek kurumsal hamleler yapmalarına olanak tanıdığ1 düşünülmektedir (Bulut vd, 2009: 518). Pazar odaklı işletmeler, kendilerini sürekli dış çevreyle ilişki içerisinde bulunan açık bir sistem olarak görmektedirler.

Pazar odaklı anlayışın öncülerinden birisi olan Narver ve Slater'e göre pazar odaklılık boyutları (1990: 21); müşteri odaklılık, rakip odaklılık ve işlevler arası koordinasyon olmak üzere üç şekilde isimlendirilmiştir.

\subsubsection{Müşteri Odaklılık}

Literatürde son yıllarda geliştirilmiş yaklaşımlardan birisi olan pazar odaklılı̆̆ın bir alt boyutu olarak adlandırılan müşteri odaklılık kavramı; işletme yöneticilerinin ve girişimcilerin alacakları kararlarda, tüketici kitlelerinin ihtiyaçlarına ve beklentilerine odaklanmaları şeklinde ifade edilmektedir (Drucker, 1998: 369). Müşteri odaklılık anlayışını benimseyen işletmeler belirledikleri strateji ve faaliyetlerinde hedef tüketici kitlelerini maksimum fayda ve tatmin düzeyine ulaştırarak, tüketicilere marka ya da işletme hakkında olumlu izlenim kazandırmayı amaçlamaktadırlar (Bulut vd., 2009: 514; Slater ve Narver, 1995: 67).

Müşteri odaklılık kavramının, işletmelerin satış sonrası hizmetleri açısından da önemli bir yere sahip olduğu ifade edilmekte, müşteri odaklı işletmelerin sunmuş oldukları ürünlere/hizmetlere yönelik tüketicilerin görüşlerine, önerilerine ve şikayetlerine yönelik bilgilere ulaşarak, hata ya da eksiklerini giderebilme imkanına sahip oldukları vurgulanmaktadır (Akman vd., 2008: 95).

\subsubsection{Rakip Odaklılık}

Pazar odaklılık yaklaşımının alt boyutlarından olan rakip odaklılık, mevcut ve potansiyel rakiplerin güncel hareketlerinin görülebilmesine, ürünleri/hizmetleri 
hakkında bilgi sahibi olunabilmesine ve gelecekteki faaliyetlerinin tahmin edilebilmesine dair veriler sağlayan bir yaklaşımdır (Bulut vd., 2009: 520). İşletmelerin rakip odaklı yaklaşımı benimsemeleriyle rakipleri hakkında (Zhou vd., 2009: 1066);

- İşletmelerin faaliyette bulundukları piyasalardaki mevcut ve olası rakiplerin belirlenmesine yönelik veri tabanlarını,

- Rakiplerinin teknolojiden ne düzeyde yararlandıklarına dair verileri,

- Hedef tüketici kitleleri açısından etkileyici alternatifler sunup sunmadikları yönündeki bilgileri, elde etmeyi amaçladıkları ifade edilmektedir.

\subsection{3. İşlevler Arası Koordinasyon}

Literatürde gerçekleştirilen çalışmalarda pazar odaklılığın alt boyutlarından birisi olarak değerlendirilen işlevler arası koordinasyon; "Müşterilere artı değer katabilmek adına tüm işletme birimleri ile eşgüdümlü biçimde koordine edilen faaliyetler bütünü" olarak tanımlanmaktadır (Esbetan ve Martin-Consuegra, 2007: 384). İşlevler arası koordinasyon başka bir ifadeyle; müşteri ve rakiplere yönelik elde edilen bilgiler dâhilinde, işletmenin tüm birimlerinin katılımıyla hedef tüketici kitlelerinin beklentilerini karşılayacak değerlerin üretilmeye çalışılması şeklinde ifade edilmektedir (Sürer ve Mutlu, 2012: 30). İşlevler arası koordinasyonun rakip ve hedef müşteri kitlelerine ilişkin verileri tüm işletme birimlerine aktarmasının yanında, örgüt içerisindeki bütünlüğü sağlayarak verilerin müşterilere artı değer katacak biçimde kullanılmasında da etkili olduğu belirtilmektedir. Bu yönü itibariyle işlevler arası koordinasyon, pazar odaklılığın temel yapı taşı olarak açıklanmaktadır (Tekcangil, 2009: 67).

\subsection{Marka, Marka Yönetimi ve Marka Yönetim Yetenekleri Kavramları}

Marka kavramı; teknoloji ve iletişimin gelişimi ile artan ve zorlaşan rekabet koşullarının etkisi altında kalan ürün/hizmetleri tanıtan, benzerlerinden ayrıştıran, söz konusu ürün/hizmetlere kişilik kazandırarak kaliteleri hakkında bilgi veren bir unsur olarak ifade edilmektedir (Okyay, 1975: 146). Marka; herhangi bir buluşun ticari bir değer taşıması halinde kurumlara yasal olarak, müşterilere ise, duygusal anlamda tescil ettirilmiş ve isim, terim, işaret, sembol vb. şekillerde farklılaştırılmış olgular bütünü olarak tanımlanmaktadır (Elitok, 2003: 2). Yapılmış çalışmalarda marka ile kültür kavramları arasında bir ilişkinin olduğu belirtilmektedir. Kültürel unsurları oluşturan gelenek, görenek ve inançlar sisteminin, marka kavramının oluşumunda da önem teşkil etmesi, markanın kültürel bir stratejik fikir olarak ifade edilmesini beraberinde getirmiştir (Grant,2006: 55).

Marka yönetimi; tüketicilerin zihinlerinde söz konusu markaya ait ürünlerin/hizmetlerin piyasadaki diğer ürünlerden/hizmetlerden farklı olduğu algısının yerleştirilmesine yönelik girişilen faaliyetler bütünüdür (Aktuğlu, 2004: 54). Marka yönetim süreci, piyasalarda tüketicilerin ihtiyaçlarına ve beklentilerine yönelik doğru ürünlerin/hizmetlerin geliştirilebilmesi açısından gerek hedef tüketici kitlelerine yönelik verilerin toplanmasına, gerekse işletmelerin yaratmış oldukları markaları ile 
ilişkili olan değerlerini faaliyette bulundukları piyasalara etkili ve verimli bir şekilde aktarabilmelerine önemli katkılar sağlamaktadır (Vorhies vd., 2011: 739).

Marka yönetim yetenekleri; hedef tüketici kitlelerinin zihinlerinde markaya yönelik olumlu çağrışımlar yaratmak, güçlü marka değerine ve imajına ulaşarak marka bilinilirliğini arttırmak adına işletmelerin markaya dair sahip oldukları değerlerini en verimli şekilde yönetebilme becerileri olarak tanımlanmaktadır (Çifci ve Cop, 2007: 71). Marka yönetim yetenekleri, işletmelerin hedef tüketici kitlelerinin zihinlerindeki marka algısını etkileyen ve tüketicilerin markaya sadık kalmalarını sağlayan önemli bir unsurdur (Ambler vd., 2002: 14). Marka yönetim yetenekleri, hedef tüketici kitlesinin ihtiyaçlarının ve beklentilerinin doğru bir şekilde belirlenmesine olanak tanıyarak, söz konusu işletmelerin tüketici tutum ve davranışlarını etkileyebilmelerine fırsat sunmaktadır (Robert ve Dowling, 2002: 1079).

Literatürde yapılan araştırmalar kapsamında marka yönetim yetenekleri; işletmelerin rakip ve müşteri çevreleri tarafından tanınmasını sağlayan markaya dair değerlerini etkin bir şekilde yaymalarına ve kullanabilmelerine yönelik yetkinlikleri olarak tanımlanmaktadır. Dolayısıyla marka yönetim yeteneklerine açıklık getirmek adına yapılan çoğu tanım ve açıklamadan; marka kimliği, marka imajı, marka değeri, marka konumlandırması, marka sadakati, marka çağrışımları, marka farkındalı̆̆ı olarak ifade edilen markaya dair değerlerin, marka yönetim yetenekleri düzeyini belirleyen ve söz konusu yetenekleri etkileyen unsurlar olduğu dikkat çekmektedir (Vorhies vd., 2011: 753; Ambler vd., 2002: 14; Aaker, 2010: 84; Aktuğlu, 2004: 39).

Marka kimliği kavramı; piyasadaki işletmeler ve söz konusu işletmelerin sundukları ürün/hizmetlere yönelik olarak tüketicilerin zihinlerinde markanın neyi temsil ettiğine dair çağrışımlar bütünü olarak açıklanmaktadır (Şahin, 1998: 238). Marka imajının daha geniş kitlelere yönelik olarak kullanılan bir kavram olduğu düşünülmektedir. Başka bir ifadeyle marka imajı; kamuoyunun markaya yönelik algısını kapsamaktayken, marka kimliği; müşterilerin zihinlerinde markaya yönelik sahip olunan algılar bütünü olarak ifade edilmektedir (Uslu vd., 2006: 16). Marka değeri kavramı, tüketicilerin zihinlerinde marka yönetim yeteneklerinin etkin bir şekilde yönetilmesi sayesinde kazanılan marka gücü aracılığıla yaratılan olumlu ya da olumsuz izlenimlerin ürünlere/hizmetlere ve tüketicilere kattı̆̆1 değerler bütünü olarak ifade edilmektedir. Söz konusu değerler, işletmelerin pazara dair değerlerinin aktiflerinden daha önemli hale gelmesinin temel nedeni olarak görülmektedir (Cop ve Bekmezci, 2005: 69). Marka konumlandırması en genel biçimde; markaların tüketicilere sunuluş şekli olarak tanımlanmaktadır. Başka bir ifadeyle marka konumlandırması ürünlerin/hizmetlerin tüketicilere sunulması sırasında onların zihinlerinde markaya yönelik istenilen çağrışımların yaratılması adına izlenilen yöntemler bütünüdür (Elitok, 2003: 64). Literatürde marka sadakati; markaya yönelik müşteri memnuniyetlerini yansitan (Ar, 2007: 90), tüketicilerin markaya dair hissettikleri psikolojik bağlılıklarını temsil eden (Yılmaz, 2005: 260) ve markaya duyulan güvenin göstergesi niteliğinde olan (Türkmen, 2008: 31) ve söz konusu markanın tercih edilmesine yönelik davranışlarını içeren bir unsur olarak ifade edilmektedir (Selnes, 1993: 21). Literatürde marka ve marka yönetimine dair önemli katkılar sağlayan Keller 
(2003: 455) marka çağrışımlarını, tüketicilerin zihinlerinde markanın ne anlama geldiğini açıklayan ifadeler kümesi şeklinde ifade etmektedir. Güçlü bir marka değerine ulaşma gayesinin işletmelerin temel hedeflerinden birisi haline gelmesi sonucunda ortaya çıkan marka yönetim yeteneklerinin bir alt boyutu olarak geliştirilen marka farkındalığı kavramı, işletmelerin markalarına yönelik tüketici zihinlerinde yarattıkları çağrışımların düzeyini izleme yetkinlikleri olarak açıklanmaktadır (Toplu, 2009: 56).

\section{3. Örgütsel Performans Kavramı}

İşletmeler açısından son derece önemli olan örgütsel performans kavramı; belirlenen stratejik hedeflere ulaşmak için sahip olunan kaynak ve varlıkların en etkili ve verimli bir biçimde kullanılabilmesine yönelik işletmelerin sahip olduğu yetkinlik düzeyleri olarak açıklanmaktadır (Göksel, 2013: 2; Daft, 2000: 12). Günümüzde, tüm dünyayı etkisi altına alarak bir moda haline gelen örgütsel performans ölçümü, özel sektör ile birlikte yükseköğrenim ve sağlık kurumları gibi sosyal amaçlı hizmet veren kurumlar da dâhil olmak üzere kamu ve özel sektörde finansal ve finansal olmayan boyutlariyla değerlendirilmektedir (Cavalluzzo ve Ittner, 2004: 244). Finansal performans; işletmelerin stratejik planlarının uygulanma ya da uygulanabilme düzeyinin veya gerçekleştirilen faaliyetlerin etkinliğinin finansal boyutta ifade edilmesidir (Carton ve Hofer, 2006: 2-3). Yüksek düzeyde finansal performansa sahip olan işletmelerin yatırım yapabilme güçlerinin de yüksek olabileceği düşüncesi, işletmelere rekabet üstünlüğü sağlayarak yeni yatırımların artmasını beraberinde getirebilecek ve onların finansal performans düzeylerin artmasına katkı verecektir (Aydeniz, 2009: 264).

Günümüzde geniş kapsamlı performans ölçüm türü olarak işletme başarı düzeylerinin belirlenmesinde etkili olan finansal olmayan performans ölçümü, işletmelerin (Elitaş ve Ağca, 2006: 345);

- Müşterilerinin sadakat ve memnuniyetlerinin,

- Ürün kalitelerinin,

- İnsan kaynakları tarafından yürütülen mali olmayan faaliyetlerinin,

- Ar-Ge çalışmaları ile gerçekleştirdikleri yeniliklerin,

- Pazar paylarının belirli metotlar ile ölçülmesi olarak tanımlanması şeklinde ifade edilmektedir.

\subsection{Değişkenler Arasındaki İlişkiler}

Son yıllarda, sosyal, siyasal ve ekonomik alanlarda yaşanan gelişmelere bağlı olarak hız kazanan bilgi ve iletişim teknolojilerindeki gelişmeler, iş yaşamında modern pazarlama anlayışının benimsenmesi ile sonuçlanmıştır. Dolayısıyla günümüzde, işletmelerin pazar paylarını koruyabilmek ve faaliyetlerini başarılı bir şekilde devam ettirebilmek adına hedef tüketici kitlelerini etkileyerek güçlü rakipleri karşısında önemli bir avantaj elde edebilmeleri zorunluluk halini almıştır. Söz konusu zorunluluk dâhilinde geliştirilen yaklaşımlardan birisi olarak kabul edilen pazar odaklılık kavramı, işletme faaliyetlerinin hedef tüketici kitlelerine, rakiplere ve birimleri 
arasındaki koordinasyona odaklı bir biçimde yürütülmesi şeklinde ifade edilmektedir. Bu yüzden literatürde, işletme faaliyetlerinin temel dayanağı olarak nitelendirilebilen pazar odaklılığa ve pazar odaklılığın işletmelerin performansına olan katkısının belirlenmesine yönelik pek çok çalışma olduğu dikkat çekmektedir. Bu çalışmalar incelendiğinde; pazar odaklı anlayışın örgütsel performans üzerinde anlamlı düzeyde etkili olduğu bulgusuna ulaşan çalışmaların varlığı görülmektedir (Zhou vd., 2009; Kohli ve Jaworski, 1990).

Literatürde yoğun bir ilgi görerek tartışma konusu olan pazar odaklılık yaklaşımına yönelik pek çok çalışma yapılmıştır. Sözkonusu çalışmalarda pazar odaklılığın marka yönetimi ve marka yönetim yetenekleri üzerinde de anlamlı bir etkisinin olduğu belirtilmektedir (Külahlı, 2016; Kohli ve Jaworski, 1990). Literatürde yapılan araştırmalar incelendiğinde; marka yönetim yetenekleri ile finansal performans arasında anlamlı bir ilişki olduğu açıklanırken (Aydın ve Ülengin, 2011; Kim vd., 2003; Lassar vd., 1995; Simon ve Sullivan, 1993) marka yönetim yetenekleri ile finansal olmayan performans arasında da anlamlı bir ilişki olduğu ifade edilmektedir (Turan, 2011; Baldauf vd., 2003).

\section{YÖNTEM}

Araştırmanın amacı; otomotiv sektöründe önemli pazar payına sahip olan işletmelerin marka yönetim yetenekleri, pazar odaklılık ve örgütsel performans düzeyleri arasında bir ilişkinin olup olmadığını belirlemektir. Araştırma; Balıkesir ve Çanakkale illerinde farklı otomotiv şirketlerinin mümessilliğini, bayiliğini ve/veya servis hizmetlerini yürüten firmalar ile sınırlandırılmıştır. Zaman ve mekân kısıtı nedeniyle araştırmanın sadece söz konusu illerde uygulanması araştırmanın kısıtını oluşturmaktadır. Araştırmanın diğer bir kısıtı; sadece otomotiv sektöründe çalışanlar üzerinde yapılmış olmasıdır. Buna ilaveten her bir işletmede satış şefi ve satış temsilcisi sayıları daha fazlayken, satış müdürlerinin sayıca daha az olması da araştırma kısıtlarından birisini oluşturmaktadır.

Araştırmada evreni belirleyebilmek amacıyla söz konusu markaların iletişim bilgilerinden yararlanılarak yapılan görüşmelerde Çanakkale ve Balıkesir illerinde söz konusu birimlerde görev yapan toplam 541 kişinin görev yaptığ1 belirlenmiştir. Araştırmada basit tesadüfi örnekleme yöntemi seçilmiş, çalışma söz konusu işletmelerde görev yapan, gün içerisinde çalışıyor durumda olan ve anketi yanıtlayan 330 kişi ile gerçekleştirilmiştir. Bundan dolayı araştırmada evrenin \%61'lik kısmına ulaşılmıştır. Araştırmada veri toplamak amacıyla anket tekniği kullanılmıştır.

Anketin ilk bölümünde demografik bilgilere, ikinci bölümünde ise pazar odaklılık, marka yönetim yeteneği ve örgütsel performans ölçeklerine yer verilmiştir. Marka yönetim yeteneklerini ölçen anket; Vorhies vd.'nin (2011) çalışmasında yer alan toplamda " 5 " soru yer alan ölçekten uyarlanmıştır. İşletmelerin örgütsel performanslarını ölçen değişkenler; Garcia-Morales vd. (2007) ile Delaney ve Huselid (1996)' in çalışmalarında yer verilen performans boyutu kullanılarak hazırlanmış ve toplamda "8" soru ile katılımcılara uyarlanmıştır. 
İşletmelerin pazar odaklılık boyutunu ölçen ve rakip odaklılık, müşteri odaklılık ile işlevler arası koordinasyon alt boyutlarından oluşan değişkenler; Theodosiou vd. (2012) ile Zhou vd.'nin (2009) çalışmasında yer verilen pazar odaklılık boyutu kullanılarak hazırlanmış ve toplamda 15 soru ile katılımcılara uygulanmıştır. Sözkonusu ölçeklerde yer alan değişkenlerin seçenekleri (1) Kesinlikle Katılmıyorum, (2) Katılmıyorum, (3) Kararsızım, (4) Katılıyorum, (5) Kesinlikle Katılıyorum şeklinde kodlanmıştır. Çalışmada aşağıda belirtilen hipotezler oluşturulmuştur.

- H1: Pazar odaklılık artarken marka yönetim yetenekleri de artmaktadır.

- H2: Pazar odaklılık, marka yönetim yetenekleri üzerinden dolaylı olarak örgütsel performans düzeyini etkilemektedir.

- H3: Marka yönetim yetenekleri artarken örgütsel performans düzeyi de artmaktadır.

Yukarıda ifade edilen hipotezlere ilişkin araştırma modeli Şekil 1'de gösterilmiştir.

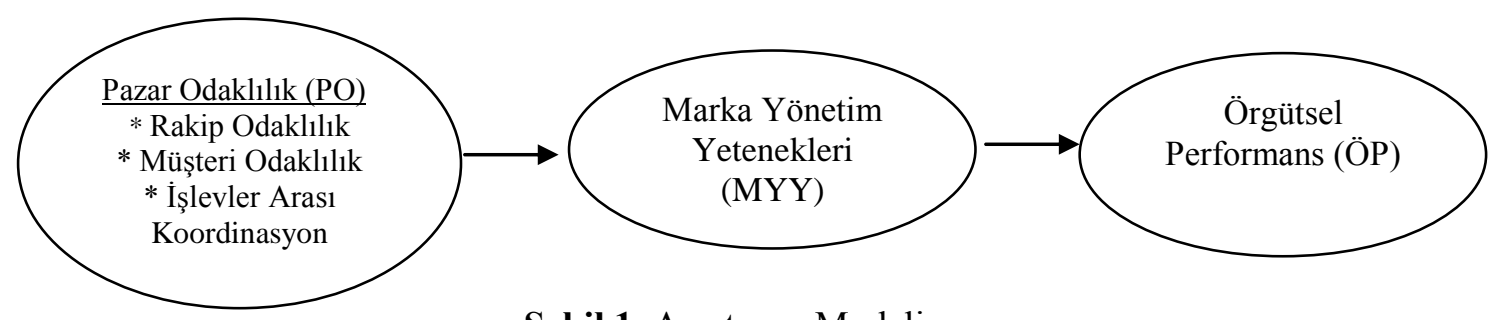

Şekil 1. Araştırma Modeli

\section{ARAŞTIRMA BULGULARI VE DEĞERLENDİRMELER}

Araştırmanın bu kısmında katılımcıların demografik özelliklerine, ölçeklerin güvenilirliklerine, doğrulayıcı faktör analizi ve yapısal eşitlik modeli bulgularına yer verilmiştir. Araştırma modeli LISREL hazır yazılımı ile sınanmış ve araştırma bulguları yapısal eşitlik modeli ile yorumlanmıştır.

\subsection{Frekans Analizi Bulguları}

Anket çalışması uygulanan katılımcılara ilişkin demografik bilgiler ile diğer bilgilerine yönelik frekans dağılımları Tablo 1'de gösterilmiştir. 
Tablo 1. Katılımcıların Demografik Özellikleri ve Diğer Bilgilerine Yönelik Frekans Dağılımları

\begin{tabular}{|c|l|r|r|}
\hline Değişkenler & \multicolumn{1}{|c|}{ Özellikler } & Say1 & \multicolumn{1}{c|}{ Yüzde } \\
\hline \multirow{4}{*}{ Cinsiyet } & Erkek & 120 & 36,4 \\
\cline { 2 - 4 } & Kadın & 210 & 63,6 \\
\hline \multirow{4}{*}{ Eğitim Durumu } & Lise & 63 & 19 \\
\cline { 2 - 4 } & Yüksekokul & 62 & 18,8 \\
\cline { 2 - 4 } & Üniversite & 189 & 57,3 \\
\cline { 2 - 4 } & Yüksek Lisans/Doktora & 16 & 4,9 \\
\hline \multirow{4}{*}{ Unvan } & Satıs Temsilcisi & 265 & 80,4 \\
\cline { 2 - 4 } & Satş Şefi & 14 & 4,2 \\
\cline { 2 - 4 } & Satış Müdürü veya Yöneticisi & 51 & 15,4 \\
\hline \multirow{5}{*}{ Yaş Grubu } & 21-25 yaş & 35 & 10,7 \\
\cline { 2 - 4 } & 26-30 yaş & 106 & 32,1 \\
\cline { 2 - 4 } & 31-35 yaş & 104 & 31,5 \\
\cline { 2 - 4 } & $36-40$ yaş & 32 & 15,7 \\
\cline { 2 - 4 } & $40+$ yaş & 213 & 10 \\
\hline \multirow{3}{*}{ Hizmet Süresi } & $0-5$ yıl & 76 & 23,6 \\
\cline { 2 - 4 } & $6-10$ yll & 41 & 12,4 \\
\cline { 2 - 4 } & $11+$ yll & & \\
\hline
\end{tabular}

\subsection{Güvenilirlik Analizi Bulguları}

Araştırmada marka yönetim yeteneklerinin başarısına katkı sağladığı düşünülen pazar odaklılık boyutunda yer alan rakip odaklılık, müşteri odaklılık ve işlevler arası koordinasyon ölçeklerinin güvenilirlikleri araştırılmıştır. Güvenilirliğin bir ölçüsü olarak Cronbach's Alpha istatistiği baz alınmış ve pazar odaklılık boyutunda yer alan ölçeklerin güvenilirlikleri 0,837 ile 0,883 arasında yer aldığı belirlenmiştir. Dolayısıyla pazar odaklılığın ölçekleri güvenilir bulunmuştur. Ölçeklerin ortalamaları da hesaplanmış ve 4,212 ile 4,515 arasında yer aldığ belirlenmiştir. Ölçeklerin güvenilirlik analiz sonuçları Tablo 2' de verilmiştir. 
Tablo 2. Pazar Odaklılık Ölçeğine Yönelik Güvenilirlik Analizi ve Tanımlayıcı İstatistikler

\begin{tabular}{|c|c|c|c|c|c|}
\hline Boyut & Madde & Ortalama & SD & $\begin{array}{l}\text { Soru Bütün } \\
\text { Korelasyon }\end{array}$ & $\begin{array}{l}\text { Soru Silindiğinde } \\
\text { Cronbach's Alpha }\end{array}$ \\
\hline \multirow{5}{*}{ 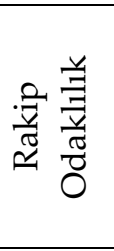 } & RO1 & 4,14 & 871 & ,359 & 816 \\
\hline & $\mathrm{RO} 2$ & 4,19 & ,922 & ,471 & ,793 \\
\hline & RO3 & 4,26 & ,762 & ,345 & ,819 \\
\hline & RO4 & 4,27 & ,846 & ,478 & ,793 \\
\hline & RO5 & 4,20 & ,865 & ,447 & ,798 \\
\hline \multicolumn{6}{|c|}{ Cronbach's Alpha $=0,837$ Ölçek Ortalama =4,212 Ölçek Varyansı =0,731 } \\
\hline \multirow{5}{*}{ 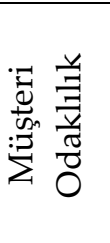 } & MO1 & 4,53 & ,736 &, 524 & 858 \\
\hline & $\mathrm{MO} 2$ & 4,60 & 631 & ,546 & ,862 \\
\hline & $\mathrm{MO} 3$ & 4,50 & ,703 & 613 & 846 \\
\hline & MO4 & 4,49 & ,757 & ,542 & ,856 \\
\hline & MO5 & 4,45 & 783 & ,497 & ,866 \\
\hline \multicolumn{6}{|c|}{ Cronbach's Alpha $=0,883$ Ölçek Ortalama $=4,515$ Ölçek Varyans $1=0,524$} \\
\hline \multirow{5}{*}{ 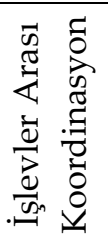 } & IAK1 & 4,17 & ,850 & ,583 & 846 \\
\hline & IAK2 & 4,17 & 880 &, 587 & 845 \\
\hline & IAK3 & 4,16 & 868 &, 504 & 852 \\
\hline & IAK4 & 4,39 & 834 & 460 & 860 \\
\hline & IAK5 & 4,22 & 901 & ,495 & 855 \\
\hline
\end{tabular}

Marka yönetim yetenekleri ölçeğinin güvenilirlik analizi yapılmış ve Cronbach's Alpha istatistiği 0,886 olarak belirlenmiş, dolayısıyla ölçek güvenilir bulunmuştur. Marka yönetim yetenekleri ölçeğinin ortalaması 4,33 olarak hesaplanmıştır. Elde edilen sonuçlar Tablo 3’ de gösterilmiştir.

Tablo 3. Marka Yönetim Yetenekleri Boyutu Güvenilirlik Analizi ve Tanımlayıcı İstatistikler

\begin{tabular}{|c|c|c|c|c|c|}
\hline Boyut & Madde & Ortalama & SD & $\begin{array}{l}\text { Soru Bütün } \\
\text { Korelasyon }\end{array}$ & $\begin{array}{l}\text { Soru Silindiğinde } \\
\text { Cronbach's Alpha }\end{array}$ \\
\hline \multirow{5}{*}{ 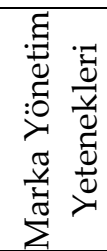 } & MYY1 & 4,50 & ,694 & 490 & 869 \\
\hline & MYY2 & 4,31 & ,768 &, 513 & 865 \\
\hline & MYY3 & 4,23 & ,838 & ,558 & 860 \\
\hline & MYY4 & 4,26 & ,783 & ,614 & 851 \\
\hline & MYY5 & 4,35 & ,750 & ,536 & 864 \\
\hline
\end{tabular}

Araştırmada örgütsel performans iki ölçekle ölçülmüştür. Bu ölçekler finansal performans (FP) ve finansal olmayan performans (FOP) olmak üzere iki boyutla toplanmıştır. Finansal performans ölçeğinde güvenirliği için Cronbach's Alpha istatistiği 0,891 olarak hesaplanmış ve ölçek güvenilir bulunmuştur. Ölçeğin ortalaması 3,613 ile en küçük ortalama olarak belirlenmiştir. Finansal olmayan performans (FOP) ölçeğinin güvenirliği için Cronbach's Alpha istatistiği 0,833 olarak hesaplanmış ve 
ölçek güvenilir bulunmuştur. Ölçeğin ortalaması 4,239 olarak hesaplanmıştır. Elde edilen sonuçlar Tablo 4'de gösterilmiştir.

Tablo 4. Örgütsel Performans Ölçeği Güvenilirlik Analizi ve Tanımlayıcı İstatistikler

\begin{tabular}{|c|c|c|c|c|c|}
\hline Boyut & Madde & Ortalama & SD & $\begin{array}{l}\text { Soru Bütün } \\
\text { Korelasyon }\end{array}$ & $\begin{array}{l}\text { Soru Silindiğinde } \\
\text { Cronbach's Alpha }\end{array}$ \\
\hline \multirow{4}{*}{ 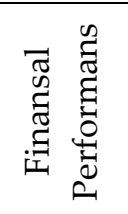 } & FP1 & 3,53 & 1,095 & ,582 & 861 \\
\hline & FP2 & 3,58 & 1,035 & 701 & ,831 \\
\hline & FP3 & 3,56 & ,985 & ,601 & ,862 \\
\hline & FP4 & 3,78 & 964 & ,498 & 881 \\
\hline \multicolumn{6}{|c|}{ Cronbach's Alpha =0,891 Ölçek Ortalama =3,613 Ölçek Varyans1 =1,042 } \\
\hline \multirow{4}{*}{ 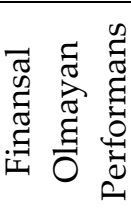 } & FOP1 & 4,28 & 848 & ,399 & 803 \\
\hline & FOP2 & 4,07 & 940 & 435 & ,794 \\
\hline & FOP3 & 4,35 & 781 & 473 & ,780 \\
\hline & FOP4 & 4,26 & 850 & ,473 & 778, \\
\hline
\end{tabular}

\subsection{Doğrulayıcı Faktör Analizi Bulguları}

Pazar odaklılık boyutunun doğrulayıcı faktör analizi (DFA) sonuçları da hesaplanmış ve ölçeklere güvenilirlik analizleri ile birlikte son hali verilmiştir. Pazar odaklı ölçekler ikinci düzey doğrulayıcı faktör analizi ile sınanmış ve elde edilen uyum ölçüleri, doğrulayıcı faktör analizi sonucunun kabul edilebilir olduğunu göstermiştir. İkinci düzey doğrulayıcı faktör analizi sonuçları Şekil 2'de gösterilmiştir. Şekil 2' ye göre üst düzey gizil değişken olan pazar odaklılık (PO); rakip odaklılık, müşteri odaklılık ve işlevler arası koordinasyon değişkenlerini açılamaktadır. Şekilde yer alan parametreler standardize edilmiş değerlerdir. İkinci düzey değişkenler için rakip odaklılık değişkeninin üst düzey değişkenle en fazla ilişkili olduğunu göstermektedir. Şekil 2'de birinci düzey gizil değişken olan rakip odaklılık (RO), 0.77 birimlik bir korelasyonla RO 4 gözlenen değişkenini (Rakiplerimizin faaliyetleri hakkında düzenli olarak bilgi toplarız) açıklamaktadır. Pazar odaklılığın alt boyutu olan diğer değişkenlerden birisi olan müşteri odaklılık (MO), 0.82 birimlik bir korelasyonla MO 3 gözlenen değişkenini (Sürekli olarak müşterilerimizin ilave ihtiyaçlarını anlamak için çabalarız) ifade etmektedir. Pazar odaklılığın diğer bir alt boyutu olan işlevler arası koordinasyon (İAK), 0.81 birimlik bir korelasyonla İAK 2 gözlenen değişkenini (İşletmemizin tüm birimleri birbirlerinin talep ve ihtiyaçlarına duyarlıdır) açıklamaktadır. Şekilde yollara ait tüm korelasyonlar anlamlı bulunmuştur. Şekil 2' de pazar odaklılık boyutuna ilişkin ikinci düzey doğrulayıcı faktör analizi bulguları gösterilmiştir. 


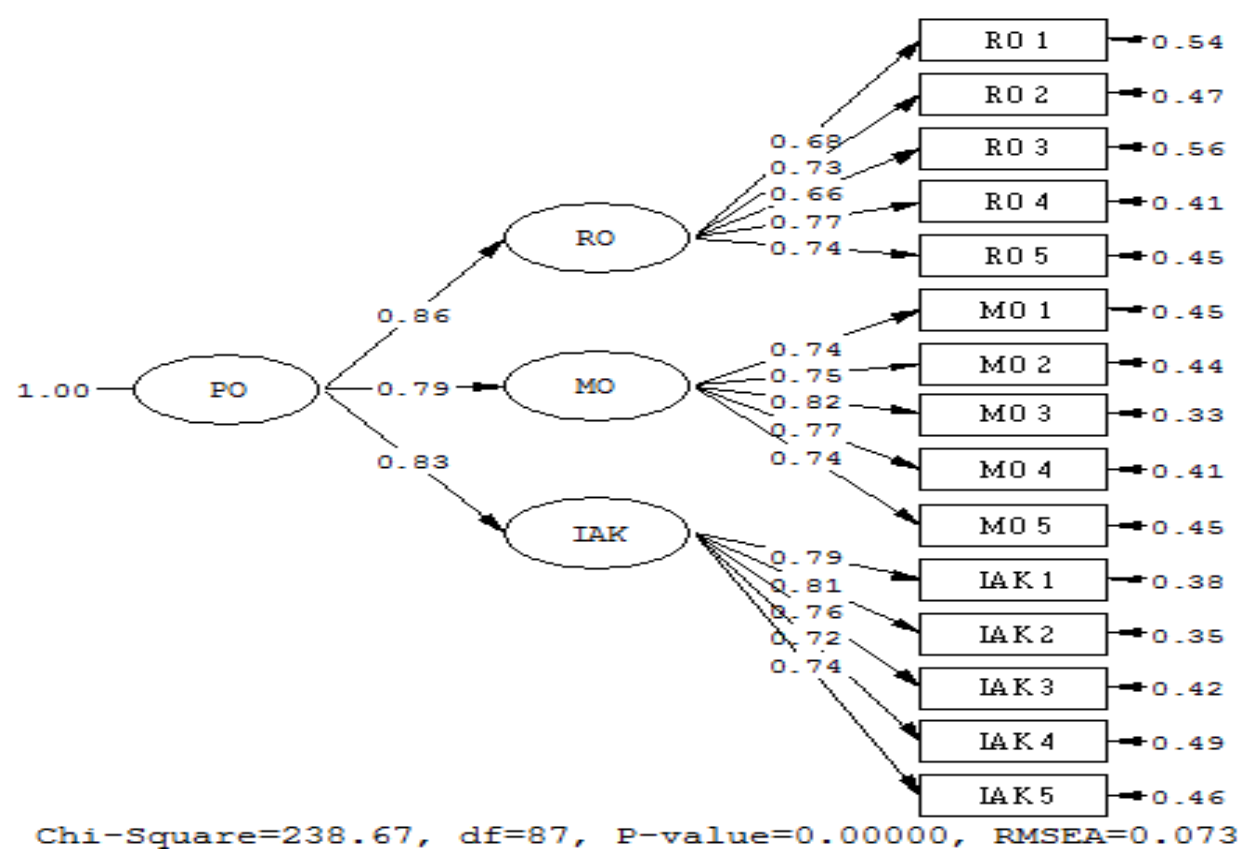

Şekil 2. Pazar Odaklılık Boyutu İkinci Düzey Doğrulayıcı Faktör Analizi

Marka yönetim yetenekleri ölçeği birinci düzey doğrulayıcı faktör analizi ile sınanmış ve elde edilen uyum ölçüleri, doğrulayıcı faktör analizi sonucun kabul edilebilir olduğunu ifade etmiştir. Birinci düzey DFA sonuçları Şekil 3'de gösterilmiştir. Şekil 3'de birinci düzey gizil değişken olan marka yönetim yetenekleri (MYY), 0,83 birimlik bir korelasyonla MYY 4 gözlenen değişkenini (Müşteri temelli marka değerini, uygun yöntemlerle, sistematik olarak arttırıyoruz) açıklamaktadır. Şekil 3'de yer alan parametreler standardize edilmiş değerlerdir ve yollara ait tüm korelasyonlar anlamlı bulunmuştur.

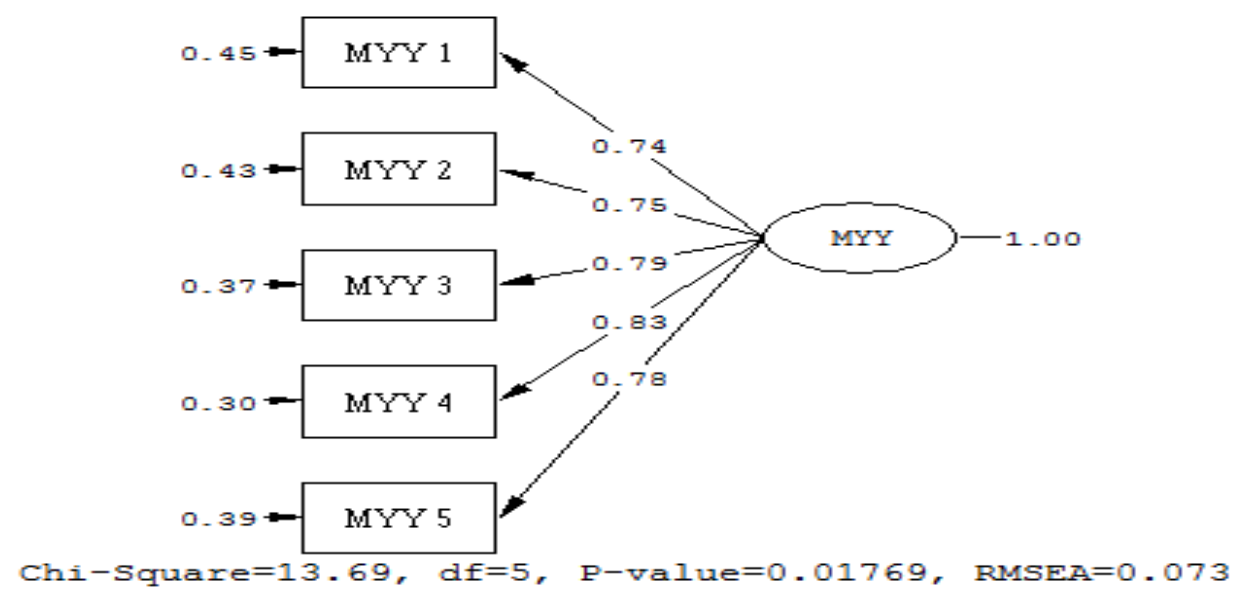

Şekil 3. Marka Yönetim Yetenekleri Boyutu Birinci Düzey Doğrulayıcı Faktör Analizi

Örgütsel performans ölçeğinin ikinci düzey doğrulayıcı faktör analizi ile sınanmış ancak model çalıştırılamamıştır. Bunun yerine her iki boyut birlikte ele alınarak sınanmış ve elde edilen uyum ölçüleri, doğrulayıcı faktör analizi sonucunun kabul edilebilir olduğunu göstermiştir. DFA sonuçları şekil $4^{\prime}$ de gösterilmiştir. Şekil 
4'e göre gizil değişken olan Finansal performans (FP), 0,91 birimlik bir korelasyonla FP 2 gözlenen değişkenini (Yatırımların kâra dönüş oranı yüksektir) açıklamaktadır. Finansal olmayan performans (FP) gizil değişkeni ise, 0,79 birimlik bir korelasyonla FOP 4 gözlenen değişkenini (Firmanın genel performansı iyiye gitmiştir) açıklamaktadır. Şekil 4 ' de yer alan parametreler standardize edilmiş değerlerdir ve yollara ait tüm korelasyonlar anlamlı bulunmuştur.

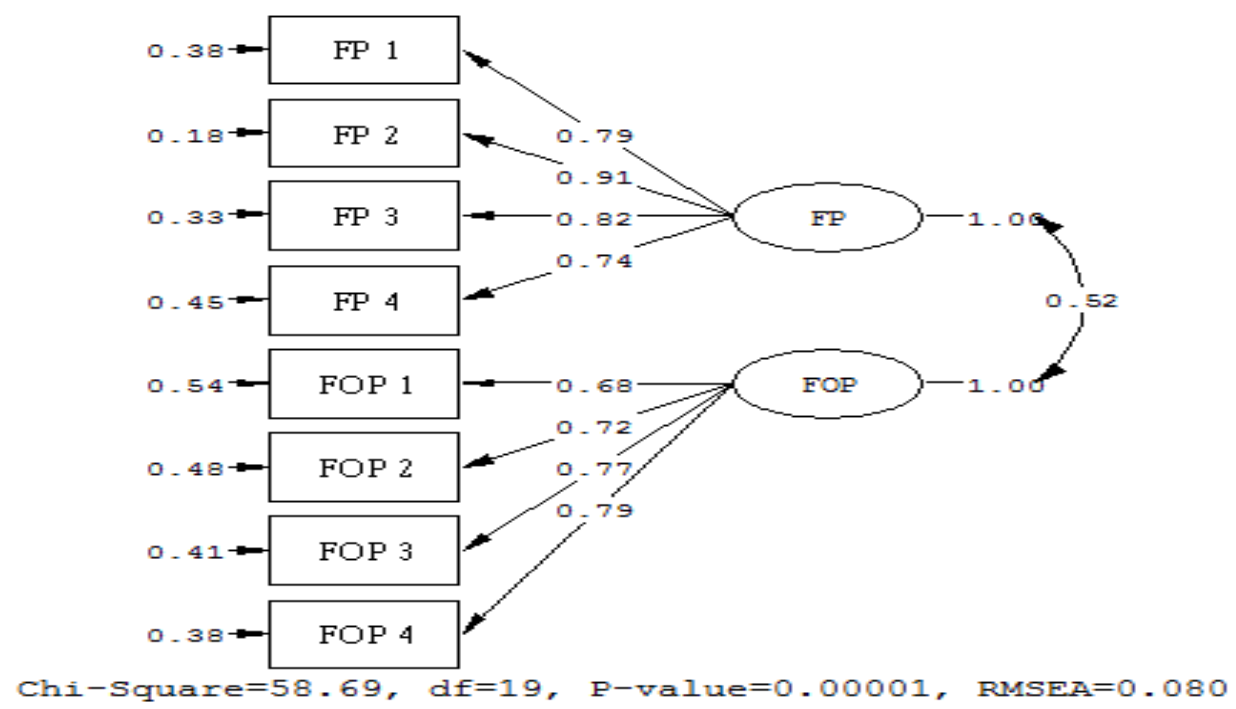

Şekil 4. Örgütsel Performans Ölçeği Doğrulayıcı Faktör Analizi

\subsection{Yapısal Eşitlik Modeli Bulguları}

Araştırmanın bu kısmında, otomotiv sektöründe faaliyette bulunan işletmelerin sahip oldukları marka yönetim yetenekleri ile örgütsel performans düzeyleri arasındaki ilişkinin yönünü ve kuvvetini görebilmek için kurulan model yapısal eşitlik modeli ile sinanmıştır Uyum ölçüleri $\chi 2=295,04 \mathrm{df} .=145 ; \chi 2 / \mathrm{df}=2,03$, RMSEA=0,056 $\mathrm{CFI}=0.99 \mathrm{NFI}=0,97 \mathrm{NNFI}=0,98 \mathrm{IFI}=0.99, \underline{\mathrm{GFI}}=0,91 \mathrm{RMR}=0.029$ olarak elde edilmiştir. Elde edilen uyum ölçüleri, yapısal modelin kabul edilebilir olduğunu göstermektedir. Modelde örgütsel performans iki boyutla ölçülmüştür. Ancak analizde bu boyutlarda yer alan gözlenen değişkenlerin ortalaması alınarak bir değişkene indirgenmiştir. Böylelikle finansal performans ve finansal olmayan performans boyutları, örgütsel performans boyutu olarak iki gözlenen değişkenle analiz edilerek tek boyuta indirgenmiştir.

Modele yönelik bulgular şekil 5'de gösterilmiştir. Model LISREL hazır yazılımı ile sınanmıştır. LISREL'de yapısal eşitlik modelinde yollara ait korelasyonlar $\mathrm{t}$ istatistiği ile sınanmaktadır. Şekil 5'de bir yol hariç diğer yollar en \%1 anlam düzeyinde anlamlı bulunmuştur. Buna göre otomotiv sektöründe faaliyette bulunan işletmelerde;

- Pazar odaklılık ile marka yönetim yetenekleri arasında aynı yönde 0,48 birimlik bir ilişki belirlenmiştir. Belirlenen bu ilişkiye göre örgütte pazar odaklı davranışta gerçekleşen bir birimlik artış marka yönetim yeteneklerini 0,48 birim artırmaktadır $(\mathrm{t}=3,15 \mathrm{p}<0,01)$. Dolayısıyla Hipotez 1 desteklenmiştir. 
- Pazar odaklılığın, marka yönetim yetenekleri üzerinden dolaylı olarak örgütsel performans düzeyini etkilediği belirlenmiştir. Dolaylı etki $0,43^{*} 0,73=0,3139$ olarak hesaplanmıştır. Dolayısıyla Hipotez 2 desteklenmiştir.

- Marka yönetim yetenekleri ile örgütsel performans düzeyi arasında aynı yönde 0,73 birimlik bir ilişki belirlenmiştir. Belirlenen bu ilişkiye göre örgütte marka yönetim yeteneklerinde gerçekleşen bir birimlik artış örgütsel performans düzeyini 0,73 birim artırmaktadır $(\mathrm{t}=6,35 \mathrm{p}<0,01)$. Dolayısıyla Hipotez 3 desteklenmiştir.

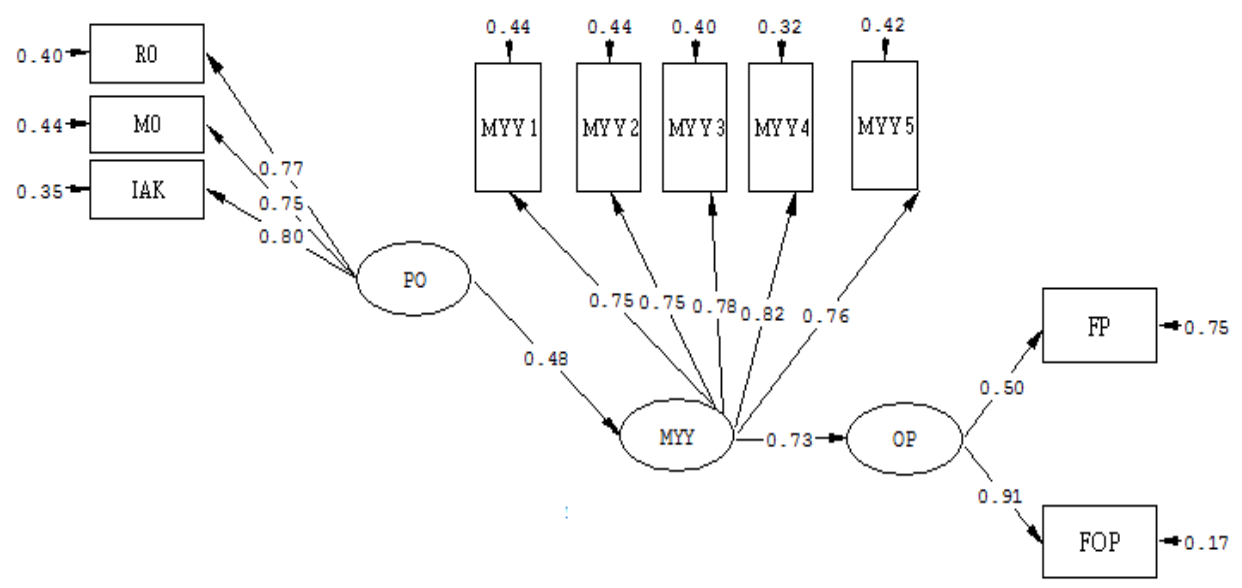

Chi-Square $=295.04, d f=145, P$-value $=0.00000, \mathrm{RMSEA}=0.056$

Şekil 5. Araştırma Hipotezleri Yol Grafiği

\section{SONUÇ ve ÖNERİLER}

Araştırmada, pazar odaklılık, marka yönetim yetenekleri ve örgütsel performans düzeyi arasındaki ilişkinin yönü ve düzeyi belirlenmeye çalışılmıştır. Buna göre elde edilen bulgular; pazar odaklılık, marka yönetim yetenekleri ve örgütsel performans düzeyinin birbirlerini pozitif yönlü ve anlamlı olarak etkilediğini göstermiştir. Yapılmış olan araştırma; literatürdeki Zhou vd. (2009) ile Kohli ve Jaworski (1990) tarafından araştırılan pazar odaklı anlayışın örgütsel performans üzerinde anlamlı düzeyde etkili olduğu bulgularıyla benzer sonuçlara ulaşmıştır. Ayrıca yapılmış olan çalışma Külahlı (2016) ile Kohli ve Jaworski (1990) tarafından araştırılan pazar odaklılığın marka yönetimi ve marka yönetim yetenekleri üzerinde anlamlı bir etkisinin olduğu bulgularıyla da örtüşmektedir. Literatürde Aydın ve Ülengin (2011), Kim vd., (2003), Lassar vd. (1995), Simon ve Sullivan (1993) tarafından yapılmış araştırmalar marka yönetim yetenekleri ile finansal performans arasında anlamlı bir ilişki olduğunu açıklamaktadır. Buna ilaveten Turan (2011), Baldauf vd. (2003) tarafından yapılmış çalışmalarda ise; marka yönetim yetenekleri ile finansal olmayan performans arasında da anlamlı bir ilişskinin olduğu belirtilmektedir. Araştırmada literatürdeki çalışmaları destekler nitelikte marka yönetim yetenekleri ile 
örgütsel performans düzeyi arasında pozitif yönlü ve anlamlı bir ilişki olduğu bulgusuna ulaşılmıştır. Başka bir ifadeyle, marka yönetim yetenekleri artarken, örgütsel performans düzeyinin de arttığı görülmüştür.

Araştırmada pazar odaklılık yaklaşımı; rakip odaklılık, müşteri odaklılık ve işlevler arası koordinasyon olmak üzere üç alt boyutta ölçülmüş ve marka yönetim yetenekleri ile olan ilişkisi değerlendirilmiştir. Elde edilen sonuçlara göre pazar odaklılığın alt boyutlarını oluşturan;

- Rakip odaklılık artarken marka yönetim yetenekleri de artmaktadır.

- Müşteri odaklılık artarken marka yönetim yetenekleri artmaktadır.

- İşlevler arası koordinasyon artarken marka yönetim yetenekleri artmaktadır.

Otomotiv sektöründe görev yapan çalışanların vermiş oldukları yanıtlar incelendiğinde, çalışanlar özellikle pazar odaklılık alt boyutunu oluşturan rakip odaklılık alt boyutunda "rakiplerimizin faaliyetleri hakkında düzenli olarak bilgi toplarız" yanıtına önem verdiklerini vurgulamışlardır. Buna göre günümüzün rekabetçi ortamında faaliyette bulunan işletmeler rakiplerinden bir adım geri kalmamak adına onların davranışlarını incelemeye ve eş biçimli davranışlar göstermeye önem verdiklerini açıklamaktadırlar. Buna ilaveten katılımcıların pazar odaklılık alt boyutunu içeren müşteri odaklılık boyutunda "Sürekli olarak müşterilerimizin ilave ihtiyaçları anlamak için çabalarız" düşüncesine önem verdikleri görülmektedir. Söz konusu bulgular, günümüz işletmelerinin üretim yapmaktan ziyade müşteri memnuniyetine dayalı bir pazarlama anlayışını tercih ettiklerini göstermektedir. Ayrıca katılımcıların pazar odaklılık alt boyutunu içeren işlevler arası koordinasyon boyutunda "İşletmemizin tüm birimleri birbirlerinin talep ve ihtiyaçlarına duyarlıdır" düşüncesine daha fazla önem verdikleri dikkat çekmektedir. İsletmelerde görev yapılan tüm birimlerin birbirlerinin ihtiyaç ve taleplerine duyarlı olmaları, söz konusu kurumlarda koordinasyon işlevine önem verildiğini ve birimlerin başarısına giden yolun bireysel amaçlardan ziyade örgütsel amaçları dikkate almaktan geçtiğini göstermektedir.

Araştırma bulguları; pazar odaklı bir anlayışa sahip olan işletmelerin, marka yönetim yetenekleri ve örgütsel performans düzeyinin artmasına katkı vereceğini açıklamaktadır. Bilgi ve iletişim teknolojilerinde yaşanan hızlı gelişim ve değişim sürecinin etkisiyle her geçen gün şiddeti artan rekabet koşullarında tüketicilerin beklenti ve ihtiyaçlarının karşılanabilmesi amacıyla işletmelerin pazar odaklı stratejileri benimsemeleri, pazarın işletme içi birimleri, rakipleri ve müşterileriyle bir bütün olarak ele alınmasını sağlayarak, işletmelere önemli bir rekabet avantajı kazandırabilecektir. Çalışmadan elde edilen bulgular pazar odaklılık kavramının alt boyutlarını oluşturan rakip odaklılık, müşteri odaklılık ve işlevler

arası koordinasyon boyutlarına önem veren işletmelerin rekabetçi yapılarını koruyarak, marka yönetim yetenekleri ve örgütsel performans düzeylerini artırabileceğini göstermektedir. Bu bağlamda özellikle işletmelerin rakip işletmelerin tehditkar hamlelerine karşı hızlı bir biçimde yanıt verme yeteneğine sahip olmaları önerilmektedir. İşletmelerin rakip işletmelerin güçlü ve zayıf yönleri ile ilgili sürekli 
bilgi toplamaları, rekabet avantajı sağlayabileceği düşünülen müşterilere odaklanmaları, rakiplerin faaliyetleri hakkında düzenli olarak bilgi toplamaları ve rakiplerin yönetim stratejilerini belirlemeye çalışmaları önem teşkil etmektedir. Müşteri memnuniyeti konusunda; işletmelerin öncelikli olarak müşteri ihtiyaçlarına hizmet etmeye odaklanmaları, müşteri memnuniyet seviyelerini sürekli ve sistematik olarak ölçmeleri, müşterilerin ilave ihtiyaçlarını anlamak için çaba göstermeleri, tüm birim ve yöneticilerin müşteri memnuniyeti için çaba sarf etmeleri dikkate alınmalıdır. Buna ilaveten özellikle yeni ürün/hizmetlerde müşterilerin ihtiyaçlarının dikkate alınması, ürün/hizmetleri müşterilerin nasıl kullanacağı konusunda beyin fırtınası yapılması, pazarın ihtiyaçlarına hizmet etmek için tüm birimlerin işlev ve faaliyetlerinin birbiri ile koordineli olması, işletmede tüm birimlerin birbirlerinin talep ve ihtiyaçlarına duyarlı olması, işletmede tüm birimlerin pazarla ilgili tüm bilgileri birbirlerine iletmeleri ve birimler arasında işletmeye rekabet avantajı sağlayan güçlü bir koordinasyonun varlığının sağlanması önem teşkil etmektedir.

\section{KAYNAKÇA}

Aaker, D. A. (2010). Güçlü Markalar Yaratmak. İstanbul: Mediacat Kitapları.

Akman, G., Coşkun Ö., Eriş, H. (2008). Strateji Odaklılık ve Firma Stratejilerinin Firma Performansına Etkisinin Analizi. İstanbul Ticaret Üniversitesi Fen Bilimleri Dergisi, 7(13), 93-115.

Aktuğlu, I. K. (2004). Marka Yönetimi: Güçlü ve Başarılı Markalar için Temel İlkeler. İstanbul: İletişim Yayınları.

Ambler, T., Bhattacharya, C.B., Edell, J., Keller, K.L., Lemon, K.N., Mitta, V. (2002). Relating Brand and Customer Perspectives on Marketing Management. Journal of Service Research, 5(1), 13-25.

Ar, A. A.(2007). Marka ve Marka Sratejileri. Ankara: Nobel Yayın Dağıtım.

Aydeniz, E. Şule. “Makroekonomik Göstergelerin Firmaların Finansal Performans Ölçütleri Üzerindeki Etkisinin Ölçülmesine Yönelik Bir Araştırma: İMKB'ye Kote Gıda ve İçecek İşletmeleri Üzerine Bir Uygulama", Marmara Üniversitesi İktisadi ve İdari Bilimler Fakültesi Dergisi, Cilt:27, Say1:2, 2009, 263-277.

Aydın, G. ve Ülengin. B. (2011). Tüketici Temelli Marka Değerinin Finansal Performans Üzerine Etkisi. İstanbul Teknik Üniversitesi Dergisi, 10(2), 58-68.

Baldauf, A., Cravens, K.S., Binder, G. (2003). Performance Consequences of Brand Equity Management: Evidence From Organizations in The Value Chain. The Journal of Product and Brand Management, 12( 4), 220-236.

Bulut, Ç., Yılmaz, C., Alpkan, L. (2009). Pazar Oryantasyonu Boyutlarının Firma Performansına Etkileri. Ege Akademik Bakış, 9(2), 513-538.

Carton, R. B. and Hofer, C.W. (2006). Measuring Organizational Performance: Metrics For Entrepreneurship And Strategic Management Research. USA: Edward Elgar Publishing Limited.

Cavalluzzo, K S. and Ittner, C.D. (2004). Implementing Performance Measurement Innovations: Evidence From Government. Accounting, Organizations and Society, 29, 243-267. 
Cop, R. ve Bekmezci, M. (2005). Marka ve Bilinirliği Yüksek Markalı Çamaşır Deterjanı Üzerine Bir Uygulama. Ticaret ve Turizm Eğitim Fakültesi Dergisi, 1, 66-81.

Çifci, S. ve Cop, R. (2007). Marka ve Marka Yönetimi Kavramları: Üniversite Öğrencilerinin Kot Pantolon Marka Tercihlerine Yönelik Bir Araştırma. Finans, Politik ve Ekonomik Yorumlar, 44(512), 69-88.

Daft, L. R. (2000). Management. Orlando: Dryden Press.

Delaney, J. T., Huselid, M.A. (1996). The Impact of Human Resource Management Practices on Perceptions of Organizational Performance. Academy of Management, 39(4), 949-969.

Drucker, P. F. (1998). Gelecek İçin Yönetim; 1990'lar ve Sonrası, (Çev. F. Üçcan). Ankara: Türkiye İş Bankası Kültür Yayınları.

Elitaş, C. ve Ağca, V. (2006). Firmalarda Çok Boyutlu Performans Değerleme Yaklaşımları: Kavramsal Bir Çerçeve. Afyon Kocatepe Üniversitesi İktisadi ve İdari Bilimler Fakültesi Dergisi, 8(2), 343-370.

Elitok, B. (2003). Hadi Markalaşalım. Ankara: Sistem Yayıncılık.

Esbetan, A., Martin-Consuegra, D. (2007). Market Orientation and Business Performance: An Empirical Investigation in The Airline Industry. Journal of Air Transport Management, 13(6), 383-386.

Garcia-Morales, V.J., Lloréns-Montes, F.F., Verdú-Jover. A.J. (2007). Influence Of Personal Mastery On Organizational Performance Through Organizational Learning and Innovation in Large Firms and SMEs. Technovation, 27, 547-568.

Göksel, A. (2013). İşletmelerde Performans Değerleme Sistemi Tasarımı: Teori-UygulamaModel. Ankara: Nobel Yayınları.

Grant, J. (2006). Markalarm İnovasyon Manifestosu.(Çev. A. Özer). İstanbul: Mediacat Kitaplar1.

Keller, K. L. (2003). Strategic Brand Management: Building, Measuring and Managing Brand Equity. New Jersey: Prentic Hall Edition.

Kim, H. B., Kim, W.G., An, J.A. (2003). “The Effect of Consumer-Based Brand Equity on Firms' Financial Performance", Journal of Consumer Marketing, 20 (4), 335-351.

Kohli, A. K., Jaworski, B.J. (1990). Market Orientation: The Construct, Research Proposition and Managerial Implications. Journal of Marketing, 54 (2), 1-18.

Külahlı, A. (2016). Tüketici İlgilenimi, Müşteri Memnuniyeti ve Marka Sadakati Arasındaki İlişkiler: Akıllı Telefon ve Parfüm Ürünleri Temelinde Bir Araştırma (Yüksek Lisans Tezi). Balıkesir Üniversitesi, Balıkesir.

Lassar, W., Banwari M., Sharma, A. (1995). Measuring Costumer-Based Brand Equity. The Journal of Consumer Marketing, 12(4), 11-19.

Narver, J. C. and Slater, S. F. (1990). The Effect of A Market Orientation on Business Profitability. Journal of Martketing, 54(4), 20-35.

Okyay, E. (1975). Yeni Mamul Kararları ve Türkiye' de Uygulama. İstanbul: Menteş Kitabevi.

Robert, P. W., Dowling, G.R. (2002). Corporate Reputation and Sustained Superior Financial Performance, Strategic Management Journal. 23, 1077-1093. 
Rose, M. G. and Shoham, A. (2002). Export Performance and Market Orientation Establishing An Emprical Link, Journal of Business Research, 55 (3), 217-225.

Selnes, F. (1993). An Examination of The Effect of Product Performance on Brand Reputation, Satisfation and Loyalty. European Journal of Marketing, 27 (9), 19-35.

Simon, C. J. and Sullivan, M.W. (1993). The Measurement and Determinants of Brand Equity: A Financial Approach. Marketing Science, 12(1), 28-52.

Slater, S. F. and Narver, J.C. (1995). Market Orientation and the Learning Organization. Journal of Marketing, 59(3), 63-74.

Sürer, A. ve Mutlu, H.M. (2012). Pazar, E-Pazarlama, Girişimcilik ve Teknoloji Yönelimlerinin İhracat Performansı Üzerine Etkileri. İnternet Uygulamaları ve Yönetimi Dergisi, 3(2), 2752.

Şahin, A. (1998). Marka Kimliği. Anadolu Üniversitesi İletişim Fakültesi Dergisi, 8, 235-247.

Tekcangil, R. (2009). Örgüt Kültürü'nün Örgütsel Yenilik ve Pazarlama Yeniliği Üzerindeki Etkilerini Ölçmeye Yönelik Gazlı İçecek Sektöründe Bir Araştırma (Yüksek Lisans Tezi). Eskişehir Osmangazi Üniversitesi, Eskişehir.

Theodosiou, M., Kehagias, J., Katsikea. E. (2012). Strategic Orientations, Marketing Capabilities and Firm Performance: An Emprical Investigation In The Context of Frontline Managers In Service Organizations. Academy of Management, 41, 1058-1070.

Toplu, S. (2009). Marka Farkındalığı Yaratma Sürecinde Kültür-Sanat Sponsorluk Etkinliklerinin İncelenmesi ve Yorumlanması (Yüksek Lisans Tezi). Marmara Üniversitesi, İstanbul.

Turan, I. B. (2011). The Role of Personality Congruence, Perceived Quality and Brand Prestige on Brand Loyalty (Yüksek Lisans Tezi). Marmara Üniversitesi, İstanbul.

Türkmen, T. U. (2008). Türk Usulü Marka Olmak. İstanbul: Brifing Yayınları.

Uslu, A., Erdem, Ş., Temelli, A. (2006). İşletmelerin Tüketici Odaklı Marka Stratejisi. İstanbul: İstanbul Ticaret Odası.

Vorhies, D. W., Orr, L.M., Bush, V.D. (2011). Improvig Customer- Focused Marketing Capabilities and Firm Financial Performance via Marketing Exploration and Exploitation. Journal of the Academic Marketing Science, 39, 739-756.

Yılmaz, V. (2005). Tüketici Memnuniyeti ve İhtiyaçlarının Marka Sadakatine Etkisi: Sigara Markasına Uygulanması. Sosyal Bilimler Dergisi, 1, 257-272.

Zhou, K. Z., Brown, J.R., Dev. C.S. (2009). Market Orientation, Competitive Advantage and Performance: A Demand-Based Perspective. Journal of Business Research, 62(11), 10631070. 